\title{
EVOLUTIONARY PATTERNS AND DEVELOPMENT PROSPECTS FOR E-GOVERNMENT: A DELPHI-BASED APPROACH TO PERCEPTIONS OF THE ADMINISTRATIVE AGENT
}

\author{
Fernando A. F. FERREIRA ${ }^{1}$, Carla S. E. MARQUES ${ }^{2}$, Melanie M. REIS ${ }^{3}$, \\ Neuza C. M. Q. F. FERREIRA ${ }^{4}$, Amali ÇIPI ${ }^{5}$
}

${ }^{1}$ ISCTE Business School, University Institute of Lisbon, Avenida das Forças Armadas, 1649-026 Lisbon, Portugal

Fogelman College of Business and Economics, University of Memphis, Memphis,

TN 38152-3120, USA

${ }^{2}$ Department of Economics, Sociology and Management,

University of Trás-os-Montes e Alto Douro, Quinta dos Prados, Apartado 1013, 5001-801 Vila Real, Portugal

${ }^{3}$ School of Management and Technology, Polytechnic Institute of Santarém

Complexo Andaluz, Apartado 295, 2001-904 Santarém, Portugal

${ }^{4}$ IASK - International Association for Scientific Knowledge, Rua Prof. ${ }^{a}$ Maria Luísa Lucena,

Loja 4 - Esq., 2625-176 Póvoa Sta. Iria, Portugal

${ }^{5}$ Department of Business Administration, Faculty of Economics, University of Vlora

"Ismail Qemali", Sheshi Pavarësia, 9401 Vlorë, Albania

E-mails: ${ }^{1}$ fernando.alberto.ferreira@iscte.pt or fernando.ferreira@memphis.edu

(corresponding author); ${ }^{2}$ smarques@utad.pt; ${ }^{3}$ mimaricoto@hotmail.com;

${ }^{4}$ neuza.ferreira@iask-web.org; 5 amalia.cipi@univlora.edu.al

Received 23 November 2012; accepted 18 January 2013

\begin{abstract}
Information technology is an open door for governments to service citizens in a more timely, cost-efficient and effective manner. Even considering citizen resistance, cultural adversity or changes in the economic agents' relationship, few would contest that concern over the state of electronic government (e-government) has increased over the years. This concern has been responsible for the emergence of a wide range of new initiatives devoted to development of the information and knowledge society, which occupies a central place in government policies and planning strategies worldwide. In this paper, we aim to analyze the evolutionary patterns of e-government in Portugal and, based on an application of the Delphi technique, provide development prospects considering the perceptions of a panel of administrative agents. Despite the low use of e-government services, our study demonstrates that the administrative agent expresses overall satisfaction with its use. Additionally, the high level of modernization allows us to forecast the increased use of information and communication technologies in terms of e-government services.
\end{abstract}

Keywords: Delphi, e-government, evolutionary patterns, prospects, strategic planning, technology management.

JEL Classification: M20, O32, O33, O38. 


\section{Introduction}

As regulatory agents, governments play an important role in the modernization of any society. In this sense, the emergence of governmental initiatives devoted to development of the information and knowledge society has occupied a central place in governmental planning strategies worldwide. As defended by Lee (2010: 229), "governments around the world are implementing innovative e-government systems and services. They are using information and communication technologies [...] to enhance their internal and external operations". Castells and Cardoso (2005) strengthened this idea, arguing that a network society has been built through the adoption of technological strategies and government policies that are being spread worldwide. Starting from this premise, and considering that the literature contains several examples of e-government initiatives, key factors of success, advantages and challenges to their implementation (e.g. Gouveia 2004a; Móran 2007; Phippen 2007; Čiegis, Gineitienè 2008; Nour et al. 2008; Lee 2010; Rorissa et al. 2011; Wangwe et al. 2012) (further developments are presented in the next section), it should be highlighted that "the increase in technology and communication has changed some of [...] attitudes on the part of governments" (Evans, Yen 2006: 208). In particular, this change of attitude had (and still has) a direct impact on the way that administrative agents perform their daily activities, which in turn has a significant impact on the ability of governments to function well and provide citizens with better services. Therefore, one may assume that the perception of the administrative agent is of great importance in the analysis of e-government evolutionary patterns and, naturally, to provide development prospects.

Based on this initial background, the present paper aims to: (i) understand the current state of maturity of e-government in Portugal (i.e. its evolutionary patterns); (ii) identify the major factors that influence the use of information and communication technologies (ICTs) in terms of administrative activities; and (iii) provide development prospects based on the perceptions of a panel of administrative agents. It should be pointed out, however, that any other discussion (e.g. e-government-related concepts, developmental stages, regional asymmetries, retrospective overviews) falls outside the scope of this paper and will not be taken up here (details on these topics can be found in Evans, Yen 2006; Lee 2010).

Methodologically, considering that the Delphi technique has proven over the years to be effective in forecasting technological trends ( $c f$. Ferreira 2003; Ferreira, Monteiro Barata 2011), there is considerable scope to explore its applicability in the particular context of this study. For that purpose, our experiment involves a panel of several administrative agents from the most representative city and parish councils in Portugal. We know of no prior work using the Delphi technique to analyze the evolutionary patterns and provide development prospects for e-government in this particular context. In this sense, the study contributes to current research by offering empirical results related to the application of the Delphi technique and forecasting e-government evolutionary trends. 
The reminder of the paper is structured as follows: Section 1 presents the literature review highlighting the most recent trends in e-government; Section 2 presents a brief methodological background of the Delphi approach and justifies its application in the context of the present study; Section 3 presents the results; and the last section concludes the paper.

\section{Literature review and recent trends in e-government}

Gouveia (2004b: 12) described the information society (IS) as "a society that uses predominantly information and communication technology for the exchange of information in digital format and that supports the interaction among individuals, using methods and practices in permanent construction". In this regard, one may assume that e-government is one of the most important components of IS, which should act on three major areas of intervention: (i) e-administration, which involves public administration and political processes; (ii) e-citizens \& e-services, which is based on relationships among citizens and organizations; and (iii) $e$-society, which is a broader area related to public participation and citizenship (Cook et al. 2002; Gouveia 2007; Kažemikaitienè, Bilevičienè 2008; Ferreira 2010). It should be pointed out, however, that these three areas of intervention require available infrastructures and imply that people should be able to access them. If that is the case, "e-government represents the free flow of information that improves knowledge, opportunity, relationships, time effectiveness, and even encourages the standardization of products and ideas because citizens view a common set of information" (Evans, Yen 2006: 231). Nevertheless, one should bear in mind that because technology changes e-government practices should change accordingly. This leads governments to new challenges and requires permanent improvements and updates.

According to Amaral (2007), ICTs have been challenging the traditional channels of creating businesses and guiding government structures into e-government logic. This means that the development of the Internet operates as an integrating component of the new economy (Kažemikaitienè, Bilevičienè 2008; Ferreira 2010; Wangwe et al. 2012), leading to "mass use of PCs [personal computers], exponential growth in broadband Internet use, widespread use of mobile telecommunications, convergence between media, and content development" (Amaral 2007: 89). Following these technological trends, e-government allows what is called "e-participation". In accordance with Gouveia (2004b, 2007), Nour et al. (2008), Lee (2010) and Rorissa et al. (2011), e-participation implies increased information availability, improved ability to query and access that information, ease of interaction in Government-to-Consumer (G2C) and Consumer-toGovernment $(\mathrm{C} 2 \mathrm{G})$ relationships, and, consequently, public involvement through the use of ICTs. From this premise, and with the scope of promoting participation, usage, sharing and citizenship, the challenges of e-government involve its ability to electronically mediate, aiming to bring together the administrative, social and economic dimensions of society. In this regard, and according to Serrano (2007: 32), the role of ICTs becomes imperative for the "possibility of contact, in real time, economic agents, as well as for the search for strategic partners at different territorial levels". Figueiredo 
(2007: 136) seemed to support this idea and argued that the creation of inside-oriented infrastructures is a critical strategic mistake, which should be replaced by an orientation of "electronic delivery of services to citizens and businesses". In addition, the importance of certain concepts, such as network and interoperability, should be pointed out (Gouveia 2004b; Posch 2007; Ferreira 2010). In practical terms, such concepts are expected to overcome power conflicts, include a common language, and be able to promote protocols and facilitate information exchange. Therefore, and from a structural perspective, it is important that e-government understands and promotes interaction among the dimensions of people, processes, information and technologies (POSI 2003).

Abdulmohsen and Mayhew (2007) argued that the e-government concept includes the daily supply of services available to citizens through electronic means, such as the Internet or telephone. Currently, the Internet has become the most accessible and effective means for the provision of governmental information and services. As such, the presence of public administration (PA) on the Internet offers significant benefits and reveals increased transparency, economic development and increased public awareness, which supports the concept of "e-democracy" (for further details, see also Nour et al. 2008). Nevertheless, Molnár (2008) and Gouveia (2009) argued that the citizen-based approach of e-government (i.e. G2C) implies a review and permanent simplification of all public processes and services offered, namely in terms of regulation. Therefore, database standardization and interoperability should be seen as priorities. One should bear in mind, however, that this concept of interoperability can only be achieved with a horizontal business model for all levels of the PA, accompanied by the necessary conditions for effective cooperation among the administrative systems (Móran 2007). In this context of citizen-based approach, it is possible to present features that should be inherent to any e-government model or system: (i) it must be targeted to the life of the citizen; (ii) it should be available 24 hours per day; (iii) it must be totally available through multiple channels (e.g. Internet, telephone); and (iv) it should be made available in a "user-friendly" logic (for further developments, see Chiolas 2008; Ferreira 2010).

According to Capgemini Ernst \& Young (in Molnár 2008), there are five levels of online service sophistication (also known in the literature as "maturity levels"): (i) information, which is related to the reception of general information about processes and/or documents required; (ii) one-way interaction, which concerns downloading and filing of electronic documents; (iii) two-way interaction, in which information can be inserted without paper support (this excludes, however, the delivery of public administrative documents (e.g. certificates and receipts)); (iv) transaction, which ensures complete online transactions; and (v) personalization, which is based on a proactive citizen-based approach where there is no longer a need to submit personal information each time a citizen accesses online services (for further details, see Mulgan 2006; Wauters et al. 2007; Molnár 2008; Ferreira 2010; Lee 2010).

Following Nour et al. (2008: 448), "there has been a proliferation of e-government initiatives worldwide undertaken under different forms of government, socioeconomic settings, and technological conditions". In this sense, European countries have been revealing remarkable growth in terms of e-government initiatives and sophistication, 
which in turn has allowed them to improve significantly in terms of efficiency (for further details, see Wauters et al. 2007; OECD 2008; Capgemini et al. 2010). Figure 1 illustrates the level of sophistication of the European countries.

Figure 1 shows Austria, Ireland, Malta and Portugal as top performers (100\%) in terms of online sophistication. These countries are followed by Germany, Italy and Sweden (with 99\%). Finally, we can see Cyprus and Greece (with 70\%). As far as availability of public services is concerned, the countries' average is $82 \%$. Once again, Austria, Ireland, Malta and Portugal lead this field along with Sweden (100\%) (Fig.2).

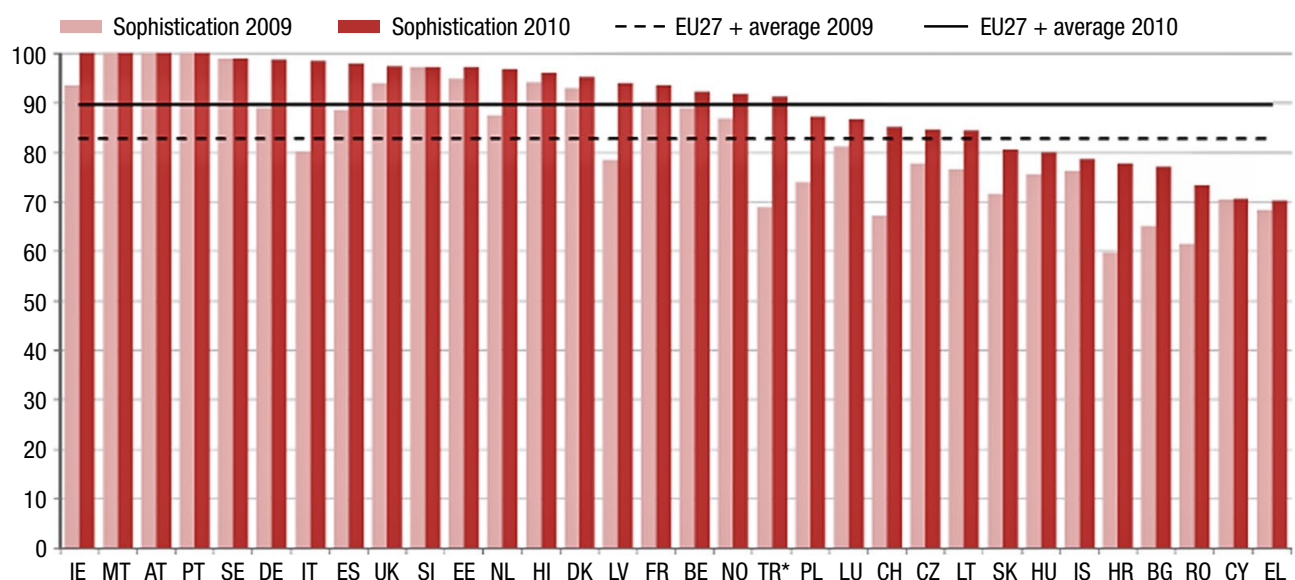

Fig. 1. Ranking of European countries by online sophistication (in \%)

Notes: * Survey not implemented in 2009. The score of 2007 is used in the graph.

Source: Capgemini et al. (2010: 7).

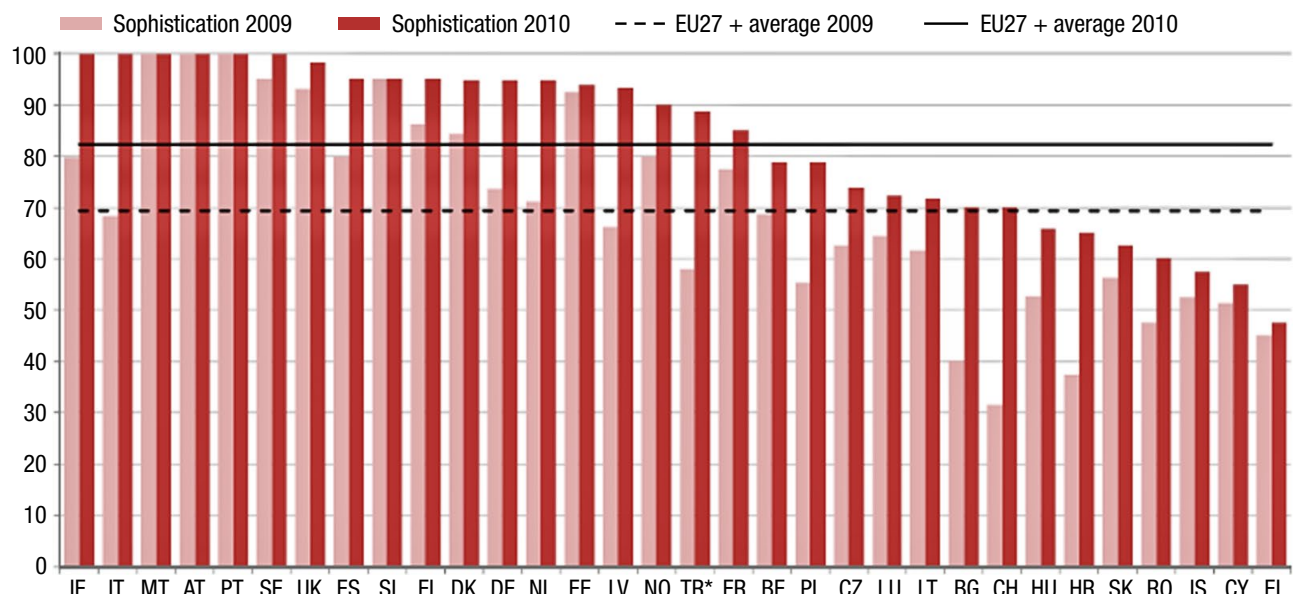

Fig. 2. Ranking of European countries by online public services (in \%)

Notes: * Survey not implemented in 2009. The score of 2007 is used in the graph.

Source: Capgemini et al. (2010: 8). 
One of the major concerns of e-government is to achieve an efficient, inclusive and transparent PA. Graafland (2003), Aykut (2007), Molnár (2008), Ferreira (2010) and Lee (2010) supported this idea and suggested that the changes that have been ongoing, in terms of how PA communicates with citizens, stem from increased citizen support of technologies that create new ways of operating online. From this premise, the transformation of PA services to electronic services, fully available anytime and anywhere, should be based on the logic of cooperation, which should not discriminate and, hence, involve all private and public entities. Additionally, "e-government is expected to play a critical role for public administration and governance in the future; [...] providing more participative opportunities for citizens" (Lee 2010: 220).

The next section presents background of the Delphi technique, which is important in understanding how the application of this technique can assist in the analysis of the evolutionary patterns, and furthermore provides development prospects for e-government in Portugal.

\section{Methodological framework}

\subsection{Basics of the Delphi technique}

In broad terms, the Delphi approach begins with the development of a survey, which should be completed individually by experts on the target topic. Specifically, as noted by Ferreira and Monteiro Barata (2011: 246), the method is based on " $a$ well-established sequence of successive individual questions supplemented with information and advice, which permits correcting the first stages of the process. [...] it is a tool, which, under certain parameters, enables consensus. [...] and is based on the rational principle that ' $n$ ' human minds are better than one when confronting the lack of precise knowledge about a certain subject".

While the method should allow for consensus, it is important to emphasize, however, that the final results should closely resemble reality. In this sense, the basic principles of a Delphi-based approach are: anonymity, controlled feedback and statistical treatment of responses. The Delphi's operational structure is shown in Figure 3 (further details can be found in Dalkey, Helmer 1963; Dalkey 1969; Hsu, Sandford 2007; Niehaves, Ortbach 2010; Ferreira, Monteiro Barata 2011; Ferreira et al. 2012).

As outlined, the results of applying the Delphi technique have a statistical basis. According to Ferreira (2003) and Ferreira et al. (2013), Delphi results are obtained through a function $G=G_{j}(I, E, R)$, which projects the response of a given group of experts $G_{j}$ to an event $E$, where $I$ is the number of experts, $E$ is the event space (which can be continuous or discrete), and $R$ is the domain of answers, which allows for an estimation for each event and expert of the group. The results may, however, be presented based on different statistical measures (e.g. central tendency - mean, median, mode or quartiles - or dispersion - standard deviation, variance or semi-interquartile amplitude). 

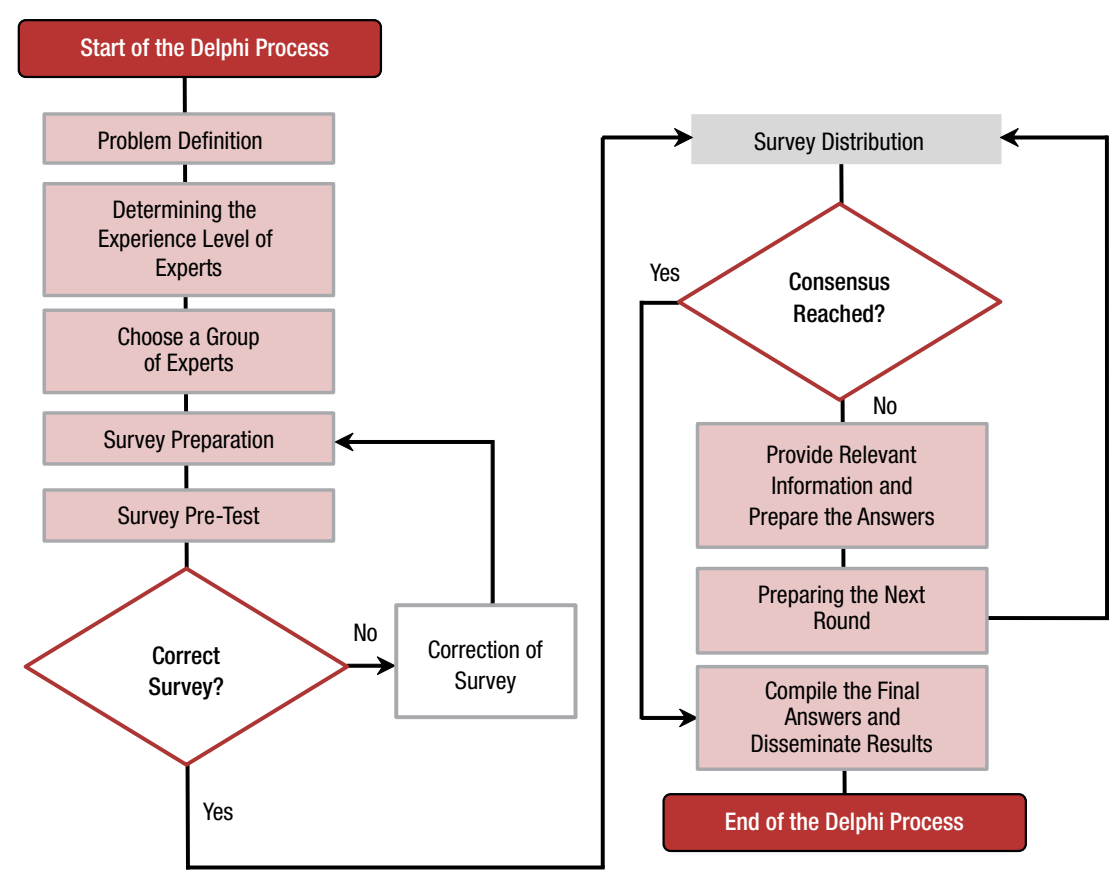

Fig. 3. Operational structure of the Delphi technique Source: Zapata in Ferreira (2003, adap.).

\subsection{Pros and cons of the Delphi technique}

It is widely acknowledged that every methodology has strengths and weaknesses. The Delphi technique is no exception, and different considerations of its pros and cons can be found in the literature (e.g. Dalkey, Helmer 1963; Dalkey 1969; Hsu, Sandford 2007; Ferreira, Monteiro Barata 2011; Ferreira et al. 2013). Figure 4 identifies some of the most discussed advantages and limitations of the Delphi technique.

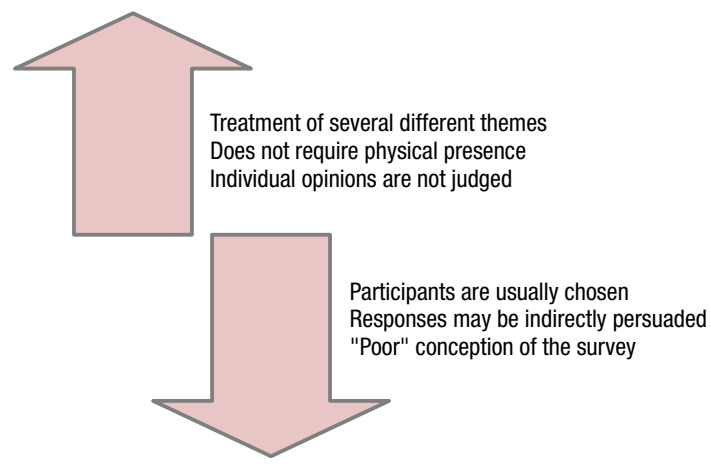

Fig. 4. Pros and cons of the Delphi technique Source: Ferreira et al. (2013, adap.). 
As Ferreira and Monteiro Barata (2011) pointed out, Delphi applications have been employed over the years in a wide range of disciplines, including economics, politics, public finance, operations management and technological innovation. The method allows for the treatment of different topics and promotes reflection on early judgments as well as possible correction of previous responses. Because the survey is individual and confidential, participants are expected to express their opinions and convictions without the influence of the organization hierarchy. In addition, it should be mentioned that the Delphi method may be applied in isolation or integrated with other approaches, allowing individuals and organizations to identify problems and search for compromise solutions based on the knowledge gleaned from the respondents' feedback. Finally, as stated by Ferreira et al. (2012), the method does not require historical data, which seems to be extremely positive when dealing with under-researched areas.

As for the cons, experts may not be readily available in many cases, limiting the scope of Delphi applications. Considering that the methodology does not require the physical presence of the participants involved, it should be noted, in terms of survey application, that respondents may misunderstand some questions, which may ultimately jeopardize the results. Also, due to the possibility of a participant feeling forced to answer according to the answers of the group, the statistical treatment of the responses provided after each round may become an influencing factor. In addition, conservative tendencies are of considerable significance here (Dalkey 1969; Ferreira et al. 2013). Finally, due to the possibility of multiple rounds, where the survey is always the same and the process becomes monotonous and/or time-consuming, respondents may no longer wish to participate and, consequently, drop out of the process. Nevertheless, considering that the Delphi technique has proven over the years to be effective in forecasting technological trends, there is considerable scope to explore its applicability in the particular context of this study. The next section presents and discusses the results achieved with an application of the Delphi technique in terms of evolutionary patterns and development prospects for e-government.

\section{Results analysis}

Taking into account the research objectives outlined for this study, the initial Delphi panel was composed of 30 administrative agents from different city and parish councils of the Portuguese territory. After the first round, the number of panel members was reduced to 15 and, after the second round, only 13 members responded to the survey. It should be noted, however, that there is no ideal number of panel members for application of the Delphi technique ( $c f$. Ferreira, Monteiro Barata 2011; Ferreira et al. 2013). Therefore, the responses from the 13 members in the final round provide the basis of our analysis.

\subsection{Panel characterization}

The reduction in the number of participants from round to round is anticipated in the literature ( $c f$. Ferreira 2003; Ferreira, Monteiro Barata 2011). Several factors can justify this reduction ( $c f$. subsection 2.2). In our case, the reduction in the number of partici- 
pants was mainly justified by the length of the questionnaire (i.e. 10 pages of multipleanswer questions). Table 1 presents a summary of data regarding the respondents in the $2^{\text {nd }}$ round.

As shown in Table 1, most respondents are male (92.31\%), mostly in the age group of $32-41$ years $(69.23 \%)$. As far as qualification is concerned, most of the panel members hold a higher academic degree $(76.92 \%)$. Also, the predominant areas of qualification are engineering and other (38.46\% for both). The data obtained according to the structure of the questionnaire are presented in the next subsection.

Table 1. Characterization of the respondents (second round)

\begin{tabular}{|c|c|c|c|}
\hline \multicolumn{4}{|c|}{ Delphi Panel } \\
\hline & & $\mathrm{N}$ & $\%$ \\
\hline \multirow{3}{*}{ Gender } & Female & 1 & 7.69 \\
\hline & Male & 12 & 92.31 \\
\hline & Total & 13 & 100.00 \\
\hline \multirow{7}{*}{ Year of birth } & $1960-1965$ & 1 & 7.69 \\
\hline & $1966-1970$ & 2 & 15.39 \\
\hline & $1971-1980$ & 9 & 69.23 \\
\hline & $1981-1985$ & 1 & 7.69 \\
\hline & $1986-1990$ & 0 & 0.00 \\
\hline & 1991-1995 & 0 & 0.00 \\
\hline & Total & 13 & 100.0 \\
\hline \multirow{7}{*}{ Qualifications } & Secondary Education & 0 & 0.00 \\
\hline & Bachelor & 1 & 7.69 \\
\hline & "Licenciatura" & 10 & 76.92 \\
\hline & MSc, MBA, or Similar & 0 & 00.0 \\
\hline & DBA or $\mathrm{PhD}$ & 0 & 00.0 \\
\hline & Other & 2 & 15.39 \\
\hline & Total & 13 & 100.0 \\
\hline \multirow{4}{*}{ Area } & Business \& Economics & 3 & 23.08 \\
\hline & Engineering & 5 & 38.46 \\
\hline & Other & 5 & 38.46 \\
\hline & Total & 13 & 100.0 \\
\hline
\end{tabular}

\subsection{Characterization of the current situation}

The objective of this section is to determine the level of implementation and availability of information technology, availability of informatics, Internet access, and other technological tools supplied in the municipal services. Based on data collected from the panel 
of experts (see Table 2), one can see that information technology is fully implemented in several municipal services $(62 \%)$, while informatics tools are only partially available $(85 \%)$.

For the next question, we tried to understand the participants' opinions about what technological tools were more important in providing high-quality services. Based on a Likert scale from 1 to $5(1=$ not important, $3=$ moderately important, $5=$ decisively important), the respondents elected infrastructure, intra-service platforms, programs of document management and programs of economic and financial management as the most important technological tools (Table 3).

Table 4 presents the results based on the availability of the Internet to municipal workers, Internet use for the development of their work activities, and adequacy of data communication speed through the Internet. In the first section of the table, most of the respondents affirm that the Internet is available to all workers (54\%), followed by a considerable number who say that the Internet is available only for some workers $(46 \%)$. In the next section, the answers indicate that the Internet is imperative (62\%) for the development of respondents' work activities, while $38 \%$ say that it is very important. In the third section, $61 \%$ of the respondents say that the speed of data communication through the Internet is appropriate. However, 23\% say that the speed is unsuitable and, paradoxically, some argue that is very appropriate or not at all suitable (8\%, respectively).

The second part of the survey analyzed the main results obtained with the use of ICT in the daily functions of municipal workers.

Table 2. Level of implementation of information technology and availability of informatics

\begin{tabular}{ccccc}
\hline & $\begin{array}{c}\text { Level of implementation of information } \\
\text { technology in municipal services (\%) }\end{array}$ & \multicolumn{2}{c}{$\begin{array}{c}\text { Level of availability of informatics } \\
\text { tools (\%) }\end{array}$} \\
\hline Fully implemented & In most of the services & Provided completely & Provided in part \\
\hline 62 & 38 & 15 & 85 \\
\hline Total & 100 & & 100 & \\
\hline
\end{tabular}

Notes: Coefficients of semantic confidence [mean; $\mathrm{n}=13$ ]: $\alpha=91.15 \%$ and $89.08 \%$ [respectively].

Table 3. Technological tools to provide high-quality service

\begin{tabular}{lcccc}
\hline \multicolumn{1}{c}{ Tools } & Median & Mean & $\begin{array}{c}\text { Standard } \\
\text { deviation }\end{array}$ & $\begin{array}{c}\text { Coefficient } \\
\text { of variation }\end{array}$ \\
\hline Infrastructure & 5 & 2.923 & 2.465 & 0.843 \\
\hline Internet & 4 & 3.462 & 1.713 & 0.495 \\
\hline Intra-service platforms & 5 & 4.077 & 1.656 & 0.406 \\
\hline Operating system $($ Word, Excel, etc.) & 3 & 3.000 & 1.528 & 0.509 \\
\hline Programs of document management & 5 & 4.538 & 1.391 & 0.307 \\
\hline Programs of economic and financial management & 5 & 3.846 & 1.908 & 0.496 \\
\hline
\end{tabular}

Notes: Coefficient of semantic confidence [mean; $\mathrm{n}=13$ ]: $\alpha=87.69 \%$. 
Table 4. Availability, importance and adequacy of Internet in municipal services

\begin{tabular}{|c|c|c|}
\hline & Respondents' opinion & $\%$ \\
\hline \multirow{3}{*}{ Availability of Internet to municipal workers } & Yes, to all & 54 \\
\hline & Yes, to some & 46 \\
\hline & Total & 100 \\
\hline \multirow{3}{*}{$\begin{array}{l}\text { Importance of Internet use for the development } \\
\text { of their work activities }\end{array}$} & Imperative & 62 \\
\hline & Very important & 38 \\
\hline & Total & 100 \\
\hline \multirow{5}{*}{$\begin{array}{l}\text { Adequacy of speed of data communication } \\
\text { through the Internet }\end{array}$} & Very appropriate & 8 \\
\hline & Appropriate & 61 \\
\hline & Unsuitable & 23 \\
\hline & Not at all suitable & 8 \\
\hline & Total & 100 \\
\hline
\end{tabular}

Notes: Coefficients of semantic confidence [mean; $\mathrm{n}=13$ ]: $\alpha=90.77 \% ; 90.77 \%$ and $90.00 \%$ [respectively].

\subsection{Technology and procedures related to the use of ICT}

The analysis of responses to the first question of this group was based on the following variables: better information for citizens, increased productivity, operative ease, reduced bureaucracy and reduced costs for the municipality. Based on data presented in Table 5, we can estimate the importance of these variables. It is important to clarify that, in this question, respondents had to choose the three most important variables and rank them in terms of importance $(1=$ first most important, $3=$ third most important $)$.

According to the respondents, better information for citizens and increased productivity (18 points in the ranking for both) are the most important variables resulting from the use of ICT in their daily work. It should be also noted that the third most important variable is operative ease (15 points) and, for fourth and fifth, we have a tie between reduced bureaucracy and reduced costs for the municipality (12 points for both).

Table 5. Main results obtained with the use of ICT in work

\begin{tabular}{ll}
\hline \multicolumn{1}{c}{ Variables } & Punctuation \\
\hline Better information for citizens & 18 \\
\hline Increased productivity & 18 \\
\hline Operative ease & 15 \\
\hline Reduced bureaucracy & 12 \\
\hline Reduced costs for the municipality & 12 \\
\hline Total & 75 \\
\hline
\end{tabular}

Notes: Coefficient of semantic confidence [mean; $n=13]$ : $\alpha=85.77 \%$. 
Using a Likert scale from 1 to 5 ( 1 = minimal relevance, $5=$ highest relevance $)$, Table 6 shows the main impacts of ICTs in the competitive advantage of the municipality.

Based on Table 6, and according to the respondents, new technologies have a considerable impact on procedural quickness and in the quality of service of municipal services, with median scores of 5 (critical importance) and 4 (very important), respectively. The remaining items assumed moderate importance (i.e. motivation of employees, operating capacity, possibility of more transparency and prestige/image).

Using a Likert scale ranging from 1 to $5(1=$ minimal relevance, $5=$ highest relevance $)$, Table 7 shows what factors participants considered most important for the promotion of technological change.

Accordingly, the results show that debureaucratization and proximity to citizens are the most relevant factors. However, one cannot say that there are no important factors, since the remaining items have very high scores: cost-cutting, image of municipality, response to officials and training of skilled human resources.

Table 6. Main impacts of new technologies in the competitive advantage of the municipality

\begin{tabular}{lcccc}
\hline \multicolumn{1}{c}{ Impacts } & Median & Mean & $\begin{array}{c}\text { Standard } \\
\text { deviation }\end{array}$ & $\begin{array}{c}\text { Coefficient of } \\
\text { variation }\end{array}$ \\
\hline Motivation of employees & 3 & 2.308 & 1.437 & 0.623 \\
\hline Operating capacity & 3 & 2.769 & 2.127 & 0.768 \\
\hline Possibility of more transparency & 3 & 2.846 & 2.035 & 0.715 \\
\hline Prestige/image & 3 & 2.462 & 2.145 & 0.871 \\
\hline Procedural quickness & 5 & 3.308 & 2.323 & 0.702 \\
\hline Quality of service & 4 & 3.538 & 1.941 & 0.549 \\
\hline
\end{tabular}

Notes: Coefficient of semantic confidence [mean; $\mathrm{n}=13$ ]: $\alpha=77.46 \%$.

Table 7. Important factors for the promotion of technological change

\begin{tabular}{lcccc}
\hline \multicolumn{1}{c}{ Factors } & Median & Mean & $\begin{array}{c}\text { Standard } \\
\text { deviation }\end{array}$ & $\begin{array}{c}\text { Coefficient of } \\
\text { variation }\end{array}$ \\
\hline Cost cutting & 4 & 3.615 & 1.805 & 0.499 \\
\hline Debureaucratization & 5 & 3.846 & 1.819 & 0.473 \\
\hline Image of municipality & 4 & 3.077 & 2.100 & 0.682 \\
\hline Proximity to citizens & 5 & 4.077 & 1.553 & 0.381 \\
\hline Response to officials & 4 & 2.846 & 1.908 & 0.670 \\
\hline Training of skilled human resources & 4 & 3.769 & 1.423 & 0.378 \\
\hline
\end{tabular}

Notes: Coefficient of semantic confidence [mean; $n=13$ ]: $\alpha=85.38 \%$. 


\subsection{E-government in the municipality}

The third part of the survey provided a deeper analysis particularly oriented toward the impacts of e-government in the municipality. Table 8 allows us to understand in what main areas e-government activity has been implemented. This question was based on multiple choice answers.

According to Table 8, with 11 responses, urbanism is clearly the area of e-government activity that stands out from the others. Second, we have fees and licenses and other with 6 responses each (which are often associated with geo-referencing tools, geographic information system (GIS) and the like). Next, we have environment and education (with 3 responses each), social action (2 responses) and human resources and treasury (1 response each). It should be noted that accounting and sports are not presented as areas of e-government activity, so there is clearly much work that is still to be developed.

Respondents were next asked to indicate the three main advantages of using e-government and rank them based on a Likert scale ranging from 1 to $3(1=$ first most important, 3 = third most important) (Table 9).

The results presented in Table 9 indicate that the benefit ranked in first place is debureaucratization (23 points), followed by accessibility (18 points) and quickness (15 points). On the other hand, advantages receiving the fewest votes were simplification (7 points) and cost-cutting (4 points).

\subsection{Overall evaluation}

The fourth part of the survey analyzed the overall assessment in terms of ICT availability, availability of technological resources, training in these areas and use of e-government. Table 10 presents the results regarding the overall evaluation of ICT availability.
Table 8. Areas of e-government activity in the municipality

\begin{tabular}{lc}
\hline \multicolumn{1}{c}{ Area } & Votes \\
\hline Accounting & 0 \\
\hline Education & 3 \\
\hline Environment & 3 \\
\hline Fees and licenses & 6 \\
\hline Human resources & 1 \\
\hline Social action & 2 \\
\hline Sports & 0 \\
\hline Treasury & 1 \\
\hline Urbanism & 11 \\
\hline Other & 6 \\
\hline Total & 33
\end{tabular}

Notes: Coefficient of semantic confidence [mean; $\mathrm{n}=13$ ]: $\alpha=70.77 \%$.

Table 9. Main advantages of using e-government by the municipality

\begin{tabular}{lc}
\hline \multicolumn{1}{c}{ Advantages } & Punctuation \\
\hline Accessibility & 18 \\
\hline Cost cutting & 4 \\
\hline Debureaucratization & 23 \\
\hline Quickness & 15 \\
\hline Simplification & 7 \\
\hline Total & 67 \\
\hline
\end{tabular}

Notes: Coefficient of semantic confidence [mean; $\mathrm{n}=13$ ]: $\alpha=89.23 \%$.

Table 10. Evaluation of ICT availability in the municipality

\begin{tabular}{ll}
\hline \multicolumn{1}{c}{ Evaluation } & Votes \\
\hline Very good & 3 \\
\hline Good & 8 \\
\hline Sufficient & 2 \\
\hline Negative & 0 \\
\hline Total & 13 \\
\hline
\end{tabular}

Notes: Coefficient of semantic confidence [mean; $\mathrm{n}=13$ ]: $\alpha=90.77 \%$. 
Table 11. Evaluation of available technological resources and ICT training

\begin{tabular}{lc}
\hline \multicolumn{1}{c}{ Evaluation } & Votes \\
\hline Very good & 1 \\
\hline Good & 9 \\
\hline Sufficient & 3 \\
\hline Negative & 0 \\
\hline Total & 13 \\
\hline
\end{tabular}

Notes: Coefficient of semantic confidence [mean; $\mathrm{n}=13$ ]: $\alpha=82.31 \%$.

Table 12. Evaluation of the use of e-government in the municipality

\begin{tabular}{lc}
\hline \multicolumn{1}{c}{ Evaluation } & Votes \\
\hline Fully used & 0 \\
\hline Widely used & 2 \\
\hline Used & 11 \\
\hline Underused & 0 \\
\hline Nothing used & 0 \\
\hline Total & 13 \\
\hline
\end{tabular}

Notes: Coefficient of semantic confidence [mean; $\mathrm{n}=13]$ : $\alpha=85.38 \%$.

Table 13. Initiatives that potentiate an inclusive information society

\begin{tabular}{lc}
\hline Initiatives & Votes \\
\hline $\begin{array}{l}\text { Functional alteration of the } \\
\text { contents for workers }\end{array}$ & 1 \\
\hline Increasing training & 7 \\
\hline Internet availability & 5 \\
\hline $\begin{array}{l}\text { More support for online } \\
\text { services }\end{array}$ & 10 \\
\hline $\begin{array}{l}\text { Strengthening the State } \\
\text { incentives }\end{array}$ & 4 \\
\hline Total & 27 \\
\hline
\end{tabular}

Notes: Coefficient of semantic confidence [mean; $\mathrm{n}=13$ ]: $\alpha=87.69 \%$.
Following the data presented in Table 10 , we can easily see that the respondents consider the degree of ICT availability in the municipalities to be good (8 votes). However, some panelists considered it to be very good (3 votes). Although some panelists classified ICT as sufficient (2 votes), there were no negative evaluations.

Regarding technological resources and ICT training (see Table 11), most of the participants stated that the municipality has technological and training resources. Nine considered it good, and none assessed it negatively.

As shown in Table 12, even though e-government is not fully used in the country, nor is it underused or nothing used, the participants believe that it is widely used (2 votes) or simply used (11 votes).

The next subsection presents and discusses the results achieved in terms of development prospects for e-government.

\subsection{Evolutionary perspectives}

The fifth and final part of the survey sought to analyze the future perspectives of municipal workers regarding the implementation of e-government. The necessary initiatives for wider use of e-government in the future are presented in Table 13.

According to Table 13, the initiatives considered most enhancing of an inclusive IS are more support for online services (10 votes), followed by increasing training (7 votes), Internet availability (5 votes), strengthening the State incentives (4 votes) and functional alteration of the contents for workers (1 vote). 
The next question asked the participants to rank, by order of importance $(1=$ first most important, $3=$ third most important) the three factors that they considered most important to strengthen the country's position in the European ranking of e-government development. According to Table 14 , the majority of responses focused on easy access to contents (30 points), followed by objectives of the organization (20 points) and, ranked in third place, motivation of employees (10 points).

Respondents were next asked to rank the four areas that they considered most important to invest in e-government $(1=$ most important, 4 = least important). The final ranking was the following: first, availability of online services (with 44 points); second, computer platforms (29 points); third, relationship between $m u$ nicipal services (24 points); and, fourth, relationship with public entities (21 points) (Table 15).

Based on the results achieved with this final part of the survey, our study demonstrates that the existing high level of modernization allows us to forecast the increased use of ICTs in terms of e-government services.

\section{Discussion and final remarks}

Information technology is an open door for governments to service citizens in a more timely, cost-efficient and effective manner. In the European context, Austria, Ireland, Malta and Portugal are top performers in terms of online sophistication, followed by Germany, Italy and Sweden (cf. Capgemini et al. 2010). In this regard, the desire for public administration that is citizen-based seems to be at the basis of the government policies and planning strategies of different countries, leading to the emergence of governmental initiatives devoted to development of the information and knowledge society. Starting from this premise, and considering that the literature contains several examples of e-government initiatives, key factors of success, challenges and advantages, this paper has highlighted that "the increase in technology and communication has changed some of [...] attitudes on the part of governments" (Evans, Yen 2006: 208). In particular, 
as pointed out earlier, this change of attitude had (and still has) a direct impact on the way that administrative agents perform their daily activities, which in turn has a significant impact on the ability of these governments to function well and provide citizens with better service. Thus, we assumed that the perception of the administrative agent is of great importance in the analysis of e-government evolutionary patterns and, naturally, in providing development prospects. Following this, our essay aimed to: (i) understand the current state of maturity of e-government in Portugal (i.e. its evolutionary patterns); (ii) identify the major factors that influence the use of ICTs in terms of administrative activities; and (iii) provide development prospects based on the perceptions of a panel of administrative agents. Considering these main objectives, and that the Delphi technique has proven over the years to be effective in forecasting technological trends, we explored its applicability in the particular context of our study. For that purpose, the experiment carried out involved a panel of several administrative agents from the most representative city and parish councils in Portugal. As previously stated, we know of no prior work using the Delphi technique to analyze the evolutionary patterns and provide development prospects for e-government in the particular context of this study. Thus, the study contributes to current research by offering empirical results related to the application of the Delphi technique and forecasting e-government evolutionary trends.

Based on the analysis of the empirical results, the panel's overall assessment in terms of ICT availability is considered good. Additionally, most of the participants stated that their municipality has good technological and training resources and, even though egovernment is not fully used in the country, it is widely used. On the other hand, the initiatives considered most enhancing of an inclusive IS are more support for online services, followed by increasing training, Internet availability, strengthening the State incentives and functional alteration of the contents for workers.

In looking ahead to future research, and considering that e-government initiatives require "continuous attention in terms of resources" (Lee 2010: 230), it would be important to conduct periodic studies devoted to gauging the opinions of a broader panel of administrative agents and, it is hoped, replicate the experiment and compare the results obtained in different countries. Additionally, exploratory case analyses and phenomenological studies would be interesting in supporting the theoretical frame. Empirical investigations into the distinctiveness of the components of the frame would also be needed to further the theoretical development, at both the macro and micro levels. As Evans and Yen (2006: 231) suggested, "e-government will continue to be an important topic to monitor, as it will dramatically affect the life of the individual citizen and their governments on a global scale”.

\section{Acknowledgments}

A short version of this paper was presented at the 2012 International Scientific Conference on "Contemporary Issues in Business, Management and Education", held in Vilnius, Lithuania, November 2012. The authors gratefully acknowledge the anonymous reviewers for their constructive comments and improvement suggestions. 


\section{References}

Abdulmohsen, A.; Mayhew, P. 2007. Government-to-citizens relationship: evaluating the quality of information on Saudi ministries' websites, in Proc. of the 7th European Conference on e-Government, June 2007, Haagse Hogeschool, Den Haag, The Netherlands, 1-8.

Amaral, L. 2007. A sociedade da informação [The information society], in Sociedade da Informação: O Percurso Português - Dez Anos de Sociedade de Informação: Análise e Perspectivas [Information society: the Portuguese route - ten years of information society: analysis and perspectives]. Lisbon: Edições Sílabo, 85-108.

Aykut, A. 2007. Turkish local e-governments: a longitudinal study, in Proc. of the 7th European Conference on e-Government, June 2007, Haagse Hogeschool, Den Haag, The Netherlands, 31-42.

Capgemini; IDC; Rand Europe; Sogeti; DTi. 2010. Digitizing Public Services in Europe: Putting Ambition into Action [online], [cited 10 September 2012]. Available from Internet: http:// www.google.pt/url? sa $=\mathrm{t} \& \mathrm{rct}=\mathrm{j} \& \mathrm{q}=\&$ esrc $=\mathrm{s} \& \mathrm{frm}=1 \&$ source $=$ web $\& \mathrm{~cd}=1 \& \mathrm{ved}=0$ CCEQFjAA\&u $\mathrm{rl}=\mathrm{http} \% 3 \mathrm{~A} \% 2 \mathrm{~F} \% 2 \mathrm{Fec}$.europa.eu $\% 2 \mathrm{Finformation}$ society $\% 2 \mathrm{Fnewsroom} \% 2 \mathrm{Fcf} \% 2 \mathrm{Fdocument}$. cfm\%3Faction\%3Ddisplay\%26doc_id\%3D747\&ei=vaxpUNXVG4izhAejj4CYDA\&usg=AFQj CNGa3dQiKzHIXeswmYlEe0ZXMxTpAQ

Castells, M.; Cardoso, G. 2005. A sociedade em rede: do conhecimento à acção política [The network society: from knowledge to political action], in Conferência promovida pelo Presidente da República [Conference sponsored by the President of the Republic], March 2005, Centro Cultural de Belém, Portugal.

Chiolas, C. 2008. Governo Electrónico em Portugal: Estratégia \& Implementação. MSc Dissertation, University of Aveiro.

Čiegis, R.; Gineitienè, D. 2008. Participatory aspects of strategic sustainable development planning in local communities: experience of Lithuania, Technological and Economic Development of Economy 14(2): 107-117. http://dx.doi.org/10.3846/1392-8619.2008.14.107-117

Cook, M.; LaVigne, M.; Pagano, C.; Dawes, S.; Pardo, T. 2002. Making a case for local e-government: the New York experience, in Proc. of the 2002 Annual National Conference on Digital Government Research, July 2002, California, Los Angeles, USA, 01-23.

Dalkey, N. 1969. The Delphi Method: an Experimental Study of Group Opinion [online], [cited 12 June 2012]. Available from Internet: http://www.rand.org/content/dam/rand/pubs/research memoranda/2005/RM5888.pdf

Dalkey, N.; Helmer, O. 1963. An experimental application of the Delphi method to the use of experts, Management Science 9(3): 458-467. http://dx.doi.org/10.1287/mnsc.9.3.458

Evans, D.; Yen, D. 2006. E-government: evolving relationship of citizens and government, domestic, and international development, Government Information Quarterly 23(2): 207-235. http://dx.doi.org/10.1016/j.giq.2005.11.004

Ferreira, F. 2003. Inovação tecnológica no sistema financeiro Português: evolução e perspectivas. 1st ed. Coimbra, Pé de Página Editores.

Ferreira, F.; Marques, C.; Reis, M.; Ferreira, N.; Çipi, A. 2012. Evolutionary patterns and development prospects for e-government: a Delphi-based approach to perceptions of the administrative agent; in Proc. of the 2012 International Conference on Contemporary Issues in Business, Management and Education, November 2012, Vilnius, Lithuania, 566-577.

Ferreira, F.; Monteiro Barata, J. 2011. A snapshot of the Portuguese e-banking activity: insights and a conceptual framework to allocate strategic hindrances, International Journal of Electronic Business 9(3): 238-254. http://dx.doi.org/10.1504/IJEB.2011.042544

Ferreira, F.; Spahr, R.; Gavancha, I.; Çipi, A. 2013. Readjusting trade-offs among criteria in internal ratings of credit-scoring: an empirical essay of risk analysis in mortgage loans, Journal of Business Economics and Management 14(4): 715-740.

http://dx.doi.org/10.3846/16111699.2012.666999 
Ferreira, N. 2010. Desafios na Implementação de Iniciativas de E-government Local: O Caso do Projecto ALO Digital. MSc Dissertation. University Institute of Lisbon.

Figueiredo, A. 2007. A dimensão crítica da sociedade da informação em Portugal [The critical dimension of the information society in Portugal], in Sociedade da Informação: O Percurso Português - Dez Anos de Sociedade de Informação: Análise e Perspectivas [Information society: the Portuguese route - ten years of information society: analysis and perspectives]. Edições Sílabo, 139-214.

Gouveia, L. 2004a. A administração pública local de base electrónica: questões e desafios [The local public administration electronic-based: issues and challenges], in II Conferência do Instituto Nacional de Administração, November 2004, Lisbon, Portugal.

Gouveia, L. 2004b. O local e-government: a governação digital na autarquia [The local e-government: the digital governance in local municipality], in Innovation and governance in municipalities collection (Book V). SPI Principia.

Gouveia, L. 2007. Uma perspectiva orientada ao território para o local e-government [An oriented perspective to the territory to the local e-government], Painel as autarquias na era da informação: o governo electrónico local [Panel local authorities in the information age: the electronic local government], $12^{\circ}$ CLAD, Santo Domingo, Dominican Republic.

Gouveia, L. 2009. Modelos de Governação na Sociedade da Informação e do Conhecimento [online], [cited 23 June 2012]. Available from Internet: http://homepage.ufp.pt/ lmbg/modelos apdsi.pdf

Graafland, I. 2003. Citizens and e-government: an international comparison of the demand-side of e-government, in Proc. of Second International Conference on Electronic Government, September 2003, Prague, Czech Republic, 448-451.

Hsu, C.; Sandford, B. 2007. The Delphi Technique: Making Sense of Consensus [online], [cited 23 June 2012]. Available from Internet: http://pareonline.net/pdf/v12n10.pdf

Kažemikaitienè, E.; Bilevičienè, T. 2008. Problems of involvement of disabled persons in egovernment, Technological and Economic Development of Economy 14(2): 184-196.

http://dx.doi.org/10.3846/1392-8619.2008.14.184-196

Lee, J. 2010. 10 year retrospect on stage models of e-government: a qualitative meta-synthesis, Government Information Quarterly 27(3): 220-230. http://dx.doi.org/10.1016/j.giq.2009.12.009 Molnár, S. 2008. E-government in the European Union, in R. Pintér (Ed.). Information society: from theory to political practice coursebook. Budapest, Gondolat: Új Mandátum, 146-170.

Móran, F. 2007. The challenges of interoperability in delivering European e-government services, in 4th Ministerial Conference eGovernment Conference, September 2007, Lisbon, Portugal.

Mulgan, G. 2006. Moldar de novo o estado e a sua relação com os cidadãos: o potencial das tecnologias de comunicação e informação no curto, médio e longo prazo [Shaping the new state and its relationship with citizens: the potential of information and communication technologies in the short, medium and long term], in Conferência promovida pelo Presidente da República [Conference sponsored by the President of the Republic], March 2006, Lisbon, Portugal, 205-214.

Niehaves, B.; Ortbach, K. 2010. Towards an agenda for e-government research and demographic change: a Delphi study approach, in Proc. of the 11th Annual International Digital Government Research Conference on Public Administration Online, May 2010, Puebla, Mexico, 227-228.

Nour, M.; AbdelRahman, A.; Fadlalla, A. 2008. A context-based integrative framework for egovernment initiatives, Government Information Quarterly 25(3): 448-461.

http://dx.doi.org/10.1016/j.giq.2007.02.004

OECD 2008. The future of e-government: agenda 2020, in OECD E-Leaders Conference 2008, March 2008, The Hague, The Netherlands.

Phippen, A. 2007. Evaluating citizen attitudes towards local e-government and a comparison of engagement methods in the UK, International Journal of Cases on Electronic Commerce 3(3): 55-71. http://dx.doi.org/10.4018/jcec.2007070105 
Posch, R. 2007. eIDM - The Key to Interoperable e-Services [online], [cited 8 May 2012]. Available from Internet: http://www.iaik.tugraz.at/content/about_iaik/people/posch_reinhard/

POSI 2003. Sociedade de Informação e Conhecimento como Instrumento de Desenvolvimento Regional [online], [cited 10 September 2012]. Available from Internet: http://www.qca.pt/pos/ posc.asp

Rorissa, A.; Demissie, D.; Pardo, T. 2011. Benchmarking e-government: a comparison of frameworks for computing e-government index and ranking, Government Information Quarterly 28(3): 354-362. http://dx.doi.org/10.1016/j.giq.2010.09.006

Serrano, A. 2007. O Papel da Sociedade da Informação no Aproximar das Regiões. Associação para a Promoção e Desenvolvimento da Sociedade de Informação, Fundação Portugal Telecom. Wauters, P.; Nijskens, M.; Tiebout, J. 2007. The User Challenge, Benchmarking the Supply of Online Public Services [online], [cited 10 September 2012]. Available from Internet: http:// ec.europa.eu/information_society/eeurope/i2010/docs/benchmarking/egov_benchmark_2007.pdf

Wangwe, C.; Eloff, M.; Venter, L. 2012. A sustainable information security framework for eGovernment: case of Tanzania, Technological and Economic Development of Economy 18(1): 117-131. http://dx.doi.org/10.3846/20294913.2012.661196

Fernando A. F. FERREIRA is Assistant Professor at ISCTE Business School of the University Institute of Lisbon, Portugal, and Adjunct Research Professor at the University of Memphis, TN, USA. He holds a PhD in Quantitative Methods Applied to Economics and Management from the University of Algarve, Portugal. In 2009, he was granted with a Calouste Gulbenkian Foundation fellowship for Post-Doctoral studies at the Fogelman College of Business and Economics of the University of Memphis. He has authored books, book chapters and peer-reviewed papers in ISI-listed journals such as Journal of the Operational Research Society, Management Decision, and International Journal of Strategic Property Management. He has practical experience as group facilitator and his main research interests include multiple criteria decision analysis and integrated systems for performance measurement.

Carla S. E. MARQUES is Assistant Professor of Management at the Department of Economics, Sociology and Management, University of Trás-os-Montes e Alto Douro (UTAD), Vila Real, Portugal. She holds a PhD in Management Science (2005) and coordinates the 'Innovation, Markets and Organization' research group at UTAD's Centre for Transdisciplinary Development Studies (CETRAD). Her works have been presented at numerous international conferences and published in international journals such as Service Business, Journal of Business Research, International Journal of Management and Enterprise Development, International Entrepreneurship and Management Journal and Management Research. Her research interests include innovation and entrepreneurship.

Melanie M. REIS is a MBA student at the Polytechnic Institute of Santarém and University of Évora, Portugal. Her main research interests include the impact of new technologies in Public Administration and e-government.

Neuza C. M. Q. F. FERREIRA received her MSc in Communication, Culture and Information Technologies from the University Institute of Lisbon (ISCTE/IUL), Portugal. In addition, she received academic training in Financial Institutions, Marketing and Tourism Promotion at the Central College of Commerce, Glasgow, UK. Her main research interests include the impact of new technologies in marketing and e-government. Some of her works have been published nationally and internationally.

Amali ÇIPI is a Lecturer at the University of Vlora "Ismail Qemali", Albania. She received her MBA from the University of Tirana, Albania and University of Nebraska, NE, USA. Currently, she is a PhD student at the University of Tirana, Albania. Her main research interests include corporate governance practices and Delphi applications. She has authored peer-reviewed papers and her works have been presented in international events. 